\title{
The Evaluation of Nosocomial Infections Developing in Intensive Care Units of a Tertiary University Hospital
}

\section{Üçüncü Basamak Bir Hastanade Yoğun Bakım Ünitelerinde Gelişen Hastane Enfeksiyonlarının Değerlendirilmesi}

\author{
(D)Arzu Tarakçı1, (DEsma Eroğlu' \\ 'Konya Eğitim ve Araştırma hastanesi, Konya, Enfeksiyon Hastalıkları ve Klinik Mikrobiyoloji, Konya, Türkiye
}

\begin{abstract}
Objective: Nosocomial infections (NIs) in intensive care units (ICUs) are serious problems because of high mortality and morbidity. Here, it was aimed to evaluate diagnoses, distribution and pathogens of Nls in two tertiary general ICUs (GICU) of a hospital and develop new infection control strategies based on the data.
\end{abstract}

Material and Method: Nlsfollowed in the infectious diseases department and recorded by active prospective surveillance between January 218-December 2019 in GICUs were retrospectively analyzed.

Results: Ninety-five $\mathrm{NI}$ episodes were identified in 90 patients during 8468 hospitalization days of 1189 patients in a two-year period. While NI rate in GICUswas 7.98, incidence of $\mathrm{NI}$ density was determined as 11.21. Considering the distribution of Nls, lower respiratory tract infections (LRTI) (36.8\%) were detected as highest and followed as specific laboratory findingsby pneumonia (33.6\%), ventilator-associated pneumonia (VAP) (10.5\%), central venous catheter-related bloodstream infections (CVCR-BSI) (9.4\%), laboratory-proven BSI (6.3\%) and catheter-associated urinary tract infections (CR-URI) (3.1\%). Given the distribution of the factors concerning system infections, agents leading to LRTI other than pneumonia were as follows: Acinetobacter spp. (48.7\%), Klebsiella pneumoniae (25.6\%), Pseudomonas aeruginosa (12.8\%), Serratia marcescens (5.1\%), Escherichia coli (2.5\%), Enterobacter cloacae (2.5\%) and Candida albicans (2.5\%), and $11.4 \%$ were polymicrobial.

Conclusion: Nls are inevitable entities in hospitals, especially in ICUs, andone of the vital goals of hospitals is to control and manage such a situation. Timely and appropriate therapeutici nterventions should be designed to reduce $\mathrm{NI}$ rates. If needed, catheters should be inserted with correct indication, andcatheter application should be reduced. It is importan that hospitals develop comprehensive antibiotherapy programs based on their own surveillance data.

Keywords: Intensive care unit, nosocomial infections, surveillance

\section{Öz}

Amaç: Yoğun bakım ünitelerinde (YBÜ) gelişen hastane enfeksiyonları (HE) yüksek mortalite ve morbidite sebebi olduğundan ciddi bir sorundur. Bu çalışmada üçüncü basamak genel yoğun bakım ünitesinde gelişen hastane kökenli enfeksiyonların tanıları, sistemlere göre dağıımları ve etken patojenleri değerlendirildi ve bu verilere dayalı olarak yeni enfeksiyon kontrol stratejileri geliştirilmesi amaçlandı.

Gereç ve Yöntem: Enfeksiyon Hastalıkları Kliniğince izlenen genel YBÜ'lerinde 01.01.2018-31.12.2019 tarihleri arasında aktif prospektif sürveyans ile kayıt altına alınan hastane kökenli enfeksiyonlar retrospektif olarak incelendi.

Bulgular: Genel YBÜ'lerde iki yıllık süreçte 1189 hastanın 8468 yatış günü takibinde 90 hastada 95 HE epizodu tanımlandı. Genel YBÜ'de Hastane enfeksiyon hızı 7,98; hastane enfeksiyon insidans dansitesi 11,21 olarak tespit edildi. HE dağııımına bakıldığında, hastalarda en sık pnömoni dışı gelişen alt solunum yolu enfeksiyonu $(\% 36,8)$ tespit edilirken bunu sırası ile spesifik laboratuar bulguları olan pnömoni $(\% 33,6)$, ventilatör ilișkili pnömoni (VIP) (\%10,5), santral venöz kateter ilişkili kan dolaşımı enfeksiyonu (SVKI-KDE) $(\% 9,4)$, laboratuar tarafindan kanıtlanmış KDE (LTD-KDE) $(\% 6,3)$ ve kateter ilişkili üriner sistem enfeksiyonu (KI-ÜSE) $(\% 3,1)$ izlemekteydi. Etkenlerin sistem enfeksiyonlarına göre dağılımına bakıldığında sırasıyla pnömoni dışı gelişen alt solunum yolu enfeksiyonun'da Acinetobacter spp. (\%48,7), Klebsiella pneumoniae (\%25,6), Psödomonas aeruginosa (\%12,8), Serratia marcescens $(\% 5,1)$, Escherichia coli $(\% 2,5)$, Enterobacter cloacae $(\% 2,5)$, Candida albicans $(\% 2,5)$ yer almaktaydı, \%11,4'ü polimikrobiyaldi.

Sonuç: Hastanelerde özellikle YBÜ'lerde hastane enfeksiyonlarının görülmesi kaçınılmazdır ve hastanelerin hayati önem taşıyan sağlık hedeflerinden biri de bu durumu kontrol etmek ve yönetmektir. Hastane enfeksiyonu oranların azaltmak için zamanında ve uygun terapötik girişimlerde bulunulmalıdır. intiyaç halinde doğru endikasyonla kateterler takılmalı ve kateter uygulaması azaltılmalıdır. Hastanelerin kendi sürveyans verilerine dayalı akılcı antibiyoterapi uygulama programları geliştirmeleri önemli bir noktadır.

Anahtar Kelimeler: Yoğun bakım ünitesi, hastane enfeksiyonu, sürveyans 


\section{INTRODUCTION}

Although leading to preventable morbidity and mortality in intensive care units (ICUs), nosocomial infections (NIs) are the main reason for the long hospitalization periods. Therefore, despite all strategies developed to control infections, the patients in ICUs are more likely to acquire a $\mathrm{NI}$ thant he general hospital population. Timely recognition and management of such infections is a requirement of optimal care in ICUs (1).

The control programs of Nls carried out in order to prevent the formation of these infections and performed to provide the diagnosis and treatment in a short time when Nls develop are among the important health services (2). The factors leading to the development of NIs in ICUs mayvary, or exhibit different characteristics from a hospitalto another, even between the different ICUs of the same hospital. Therefore, it is required to carry out regular surveillance in each department (3). The algorithms to determine the type of ICUs, rates of invasive vehicle-related, invasive device-patient-day-related infections and rates of device uses are the best methods for comparing in-hospital and inter-hospita linfection rates (4). The scope of surveillance has been expanded with the acceptance of Nls as novel quality indicators in hospital settings. All of the undesirable situations that develop and are likely to prevent during the healthcare process are included into the surveillance studies (5). In the present study, the diagnoses, distribution rates and causative pathogens of Nls developed in thegeneral ICUs (GICUs) of a tertiary health facility were evaluated, and in light of these data, it was aimed to develop novel infection control strategies.

\section{MATERIAL AND METHOD}

Followed by the infectious diseases department in two GICUs of our tertiary hospital, one with seven and the other with eight beds, 1189 patients were hospitalized and followedup with the active prospective surveillance method on a total of 8468 hospitalization days between January 2018 and December 2019. The study was approved by the University of Medical Sciences Konya Training and Research Hospital of Specialty in Medical Training (TUEK), dated on $5^{\text {th }}$ March 2020 and with the registration number of 36-31.

The patients over 18 years of age were included into the study, and such samples as throat, blood, catheter, urine, tracheal aspirate and bronchoalveolar lavage cultures appropriate for the physical examination findings were accumulated from the cases. The blood and sterile samples obtained were incubated in the fully-automated blood culture device of BACTEC 9240 (Becton Dickinson, Diagnostic Instrument System, Spark, USA). The specimens likely to reproduce were inoculated from the tubes onto the media of eosinmethylene-blue (EMB) agar and 5\% sheep blood agar. All petriplates were incubated at $35 \pm 2^{\circ} \mathrm{C}$ for 24 hours in aerospace environment. The colonies of isolated bacteria not fermenting lactose and having negative oxidase test results were identified using the VITEK 2 Compact ${ }^{\oplus}$ (BioMérieux, France) device, and the antibiotic susceptibilitiesof these bacteria were investigated under the criteria of The Informational Supplements to the Clinical and Laboratory Standards Institute (CLSI). Antimicrobial Susceptibility Guidelines (CLSI-2010 and CLSI-June 2010 -update) (6). Nls were defined according to the diagnostic criteria of Centers for Disease Control and Prevention (CDC) (7). A total of $95 \mathrm{Nls}$ were diagnosed over a two-year period. While the ventilator-associated pneumonia (VAP) rate was defined as the number of VAPs per 1.000 ventilator days, the rates of central venous catheter-related bloodstream infections (CVCR-BSI), catheter-related upper respiratory infection (CR-URI) and the rate of usingi nvasivedevice were calculated with the following formulae:

Rate of CVCR-BSI =Number of CVCR-BSIs /number of centralvenouscatheterdays in ICU x 1000

Ratetae of CR-URI =Number of CR-URI / number of urinary catheter days $\times 1000$

Rate of invasivedevice utilization=Number of device utilization days/number of disease days

\section{Statistical analysis}

In the statistical analyses of the data,the study findin gs were descriptively evaluated with the Statistical Package for the Social Sciences for Windows, software version 20.0, (SPSS Inc., Chicago, IL,USA).

\section{RESULTS}

In GICUs, $95 \mathrm{Nl}$ episodes were identified in 90 patients during 8468 hospitalization days of 1189 patient sover a 2-year period. Of 90 patients included into the study, 57 were male $(63.3 \%)$, and 33 were female (36.6\%). The age range of the patients was $18-99 y e a r s$, and the mean age found as $64 \pm 23$. The mean age of female patients was $68 \pm 27$, while that of male patients was calculated as $62 \pm 23$. However, the rates and incidence density of NIs were determined as 7.98 and 11.21 , respectively. The diagnoses of the patients with NIs on admission and accompanying comorbid diseases are presented in Table 1.

Among other diagnostic criteria, the patients were also diagnosed with burn injuries, mesenteric ischemia, acute cholecystitis, acute pancreatitis, pulmonary edema and gastrointestinal (GIS) hemorrhages. When the comorbid diseases accompanying the patients' clinical picture were examined except for acute diagnoses, while $19(21.1 \%)$ patients had more than two comorbidities, one and two comorbidities were seen to accompany the acute picture in 29 (32.6\%) and 27 (30\%) patients, respectively. No comorbid diseases were encountered in $15(16.6 \%)$ of the patients. Accompanying diseases, under the heading of others, included Parkinson, human immunodeficiency virus (HIV) infection, amyotrophic lateral sclerosis, multiple sclerosis and interstitial lung disease.

The number of the days fo rinvasive device utilization and infection rates followed-up in ICUs fort wo years are shown in Table 2. 


\begin{tabular}{lc}
\multicolumn{2}{l}{ Table 1. Diagnoses of patients with nosocomial infections on admission } \\
and accompanying diseases \\
\hline Diagnoses (n=95) & $\mathbf{n}(\%)$ \\
\hline Community-acquired pneumonia & $19(21.1 \%)$ \\
CVD & $12(13.3 \%)$ \\
Sepsis & $9(10.0 \%)$ \\
Acute renal failure & $8(8.8 \%)$ \\
Poor prostration due to malignancy & $7(7.7 \%)$ \\
COAH & $7(7.7 \%)$ \\
Subarachnoid hemorrhage & $5(5.5 \%)$ \\
Respiratory failure & $4(4.4 \%)$ \\
Acute coronary syndrome & $4(4.4 \%)$ \\
Heart failure & $4(4.4 \%)$ \\
Trauma & $3(3.3 \%)$ \\
Pulmonary embolism & $2(2.2 \%)$ \\
Others & $11(11.5 \%)$ \\
Accompanying diseases (n=165) & \\
Hypertension & $32(33.6 \%)$ \\
CVD & $28(29.4 \%)$ \\
COAH & $25(26.3 \%)$ \\
DM & $22(23.1 \%)$ \\
Malignancies & $16(16.8 \%)$ \\
Heart failure & $9(10.0 \%)$ \\
CAD & $8(8.8 \%)$ \\
CRF & $7(7.7 \%)$ \\
Alzheimer's & $6(6.6 \%)$ \\
Atrial fibrillation & $4(4.4 \%)$ \\
Others & $8(8.8 \%)$ \\
\hline CAD: Coronary artery disease, COAH: Chronic obstructive pulmonary disease, CRF:Chronic renal \\
failure, CVD: Cerebrovascular disease, DM: Diabetes mellitus
\end{tabular}

Table 2. Number of days and rates of invasive device utilization

\begin{tabular}{lccccc} 
& $\begin{array}{c}\text { Number of } \\
\text { days }\end{array}$ & $\begin{array}{c}\text { Rate of device } \\
\text { utilization }\end{array}$ & & $\begin{array}{c}\text { Number of } \\
\text { infections }\end{array}$ & $\begin{array}{c}\text { Rate of } \\
\text { infections }\end{array}$ \\
\hline CVC & 4407 & 0.52 & CVCR-BSI & 9 & 2.04 \\
UC & 8057 & 0.95 & CR-URI & 3 & 0.37 \\
MV & 4304 & 0.5 & VAP & 10 & 2.32 \\
\hline $\begin{array}{l}\text { CR-URI: Catheter-related upper respiratory infection, CVC: Central venous catheter, CVCR- } \\
\text { BSI: Central venous catheter-related bloodstream infections, MV: Mechanical ventilator, UC: Urinary } \\
\text { catheter, VAP: Ventilator-associated pneumonia }\end{array}$ \\
\hline
\end{tabular}

The rate of NI development in GICUs was calculated as $7.98 \%$. When the distribution of Nls was investigated, the rate of lower respiratory tract infections other than pneumonia (LRTIOP) was detected as $36.8 \%$, and this rate was followed by pneumonia having specific laboratory findings (33.6\%), ventilator-associated pneumonia (VAP) (10.5\%), central venous catheter-related bloodstream infections (CVCR-BSI) (9.4\%), laboratory-proven BSI (6.3\%) and catheter-related upper respiratory tract infections (CR-URI) (3.1\%), respectively. Considering the distribution of all NI pathogens, Gramnegative, Gram-positive pathogens and yeast were seen at the rates of $93.1 \%, 4.9 \%$ and $1.9 \%$, respectively. When Gramnegative pathogens were examined, Acinetobacter spp. Was detected to rank first as $57.8 \%$. However, Acinetobacter spp. was respectively followed by Klebsiella pneumoniae (23.1\%), Pseudomons aeruginosa (8.4\%), Escherichia coli (3.1\%),

Serratia marcescens (2.1\%), Enterobacter cloacae (2.1\%), Stenotrophomonas maltophila (1.0\%), Morganella morganii (1.0\%) and Sphingomonas paucimobilis (1.0\%), respectively. When Gram-positive pathogens were examined, coagulase negative Staphylococcus (CNS) was observed to rank first $(60 \%)$ and followed by Staphylococcus aureus (20\%) and Enterococcus faecium (20\%), respectively (Table 3).

Table 3. Agents and distributions of nosocomial infections

\begin{tabular}{|c|c|c|}
\hline Diagnoses of NIs & AgentsleadingtoNls & n (\%) \\
\hline LRTIOP & $\begin{array}{c}\text { Acinetobacter spp. } \\
\text { K. pneumoniae } \\
\text { P. aeruginosa } \\
\text { S. marcescens } \\
\text { E. coli } \\
\text { E. cloacae } \\
\text { C. albicans }\end{array}$ & $\begin{array}{l}19(48.7 \%) \\
10(25.6 \%) \\
5(12.8 \%) \\
2(5.1 \%) \\
1(2.5 \%) \\
1(2.5 \%) \\
1(2.5 \%)\end{array}$ \\
\hline $\begin{array}{l}\text { Pneumonia with } \\
\text { specific laboratory } \\
\text { findings }\end{array}$ & $\begin{array}{c}\text { Acinetobacter spp. } \\
\text { K. pneumoniae } \\
\text { E. coli } \\
\text { P. aeruginosa } \\
\text { S. aureus } \\
\text { polymicrobial }\end{array}$ & $\begin{array}{c}24(72.7 \%) \\
4(12.1 \%) \\
2(6.0 \%) \\
2(6.0 \%) \\
1(3.1 \%) \\
1(3.1 \%)\end{array}$ \\
\hline VAP & $\begin{array}{l}\text { Acinetobacter spp. } \\
\text { K. pneumoniae } \\
\text { P. aeruginosa }\end{array}$ & $\begin{array}{l}9(75.0 \%) \\
2(16.6 \%) \\
1(8.8 \%)\end{array}$ \\
\hline CVCR-BSI & $\begin{array}{c}\text { K. pneumoniae } \\
\text { Acinetobacter spp. } \\
\text { CNS } \\
\text { Stenotrophomonas maltophilia } \\
\text { C. glabrata }\end{array}$ & $\begin{array}{l}5(55.5 \%) \\
1(11.1 \%) \\
1(11.1 \%) \\
1(11.1 \%) \\
1(11.1 \%)\end{array}$ \\
\hline $\begin{array}{l}\text { Laboratory-proven } \\
\text { BSI }\end{array}$ & $\begin{array}{c}\text { CNS } \\
\text { Acinetobacter Iwoffii } \\
\text { Enterobacter cloacae } \\
\text { Sphingomona spaucimobilis }\end{array}$ & $\begin{array}{l}2(33.3 \%) \\
2(33.3 \%) \\
1(16.6 \%) \\
1(16.6 \%)\end{array}$ \\
\hline CR-URI & $\begin{array}{l}\text { K.pneumoniae } \\
\text { Morganella morganii } \\
\text { Enterococcus faecalis }\end{array}$ & $\begin{array}{l}1(33.3 \%) \\
1(33.3 \%) \\
1(33.3 \%)\end{array}$ \\
\hline \multicolumn{3}{|c|}{$\begin{array}{l}\text { BSI: Blood streaminfection, CNS: Coagulase negative staphylococcus, CR-URI: Catheter-related } \\
\text { upper respiratory tract infection, CVCR-BSI: Central venous catheter-related bloodstream infections } \\
\text { LRTIOP: Lower respiratory tract infections other than pneumonia, VAP: Ventilator-associated } \\
\text { pneumonia }\end{array}$} \\
\hline
\end{tabular}

\section{DISCUSSION}

Nowadays, the advances achieved in medical technologies in ICUs have enabled many patientst a live longer thanks to advanced equipments, also causing prolongation in hospital stays. Comorbid diseases, metabolic problems of the patients followed-up in ICUs, coming antibiotics into massuse, invasive interventions for diagnosis and treatment are the factors increasing the risks of $\mathrm{NI}$ developmentcaused by resistant pathogens in ICUs (8). In our study, the rate and the infection incidence density of NIs were determined as $7.98 \%$ and $11.21 \%$, respectively. In two studies where NIs wereevaluated in other countries, the rates of $\mathrm{NI}$ development were found to be $13 \%$ and $4.5 \%(9,10)$. However, in the studies evaluating NIs in ICUs in our country, while the rate and the infection incidence density of NIs werefoundto be $11.1 \%$ and $23.6 \%$ respectively in a study (11), another study detected the rate 
of NIs as $15 \%$ (12). Weconsider that different factors may have caused these different findings to be reported in various studies. These factors may have arisen from differences in the periods these studies were conducted, and the deficiencies in the surveillance practices of nosocomial care. In addition, the fact that Nls were examined in different units may also be a reason leading to these factors.

In a study where invasive device-associated nosocomia linfections (IDANIs) were examined, while the rates of mechanical ventilator utilization and VAP were found to be 0.46 and 1.34 respectively, ther ates of CVC use, CVCR-BSI, use of urinary catheter and CR-URI were detected as 0.72 , 8.6, 0.99 and 3.45, respectively (13). In our study, however, while the rates of mechanical ventilator utilization and VAP were found as 0.5 and 2.32, the rates of CVC use, CVCR-BSI, use of urinary catheter and CR-URI were detected as 0.52, 2.04, 0.95 and 0.37 , respectively. In hospitals, ICUs are the settings where especially critical patients are followed-up, andi nvasive interventions are used quite highly; therefore, the rates of infections in ICUs also increase (13). According to the National Nosocomial Infections Surveillance Network (UHESA) (NNISN) 2019 report, in the anesthesia and reanimation units in hospitals depending on the Ministry of Health around Turkey, the rates of mechanical ventilator utilization and VAP were found as 0.6 and 5.3 respectively, and VAP were reported to rank first as an IDANI(14). In our study, however, while the mechanical ventilator utilization rate was similar to that stated in the NNISN 2019 report, the VAP rate was lower. Because the levels of ICUs in all hospitals may be different around Turkey, the patients' profile and bedcapacity may also be different. When compared with the average rate of Turkey, the reason why our VAP rate was lower may have arisen from the different conditions in ICUs or hospitals. According to the NNISN) 2019 report, in the anesthesia andreanimation units in hospitalsdepending on theMinistry of Health aroundTurkey, the rate of CVC utilization was 0.54 ; the rate of CVCR-BSI was 4 and ranked the second frequently encountered IDANI. On the other hand, the rate of urinary catheter utilization was 0.97, and the rate of CR-URI was 1.5 and ranked as the third most frequent IDANI (14). When we compared our findings with those stated in the NNISN report 2019, IDANIs ranking second and third were seen to be CVCR-BSI and CR-URI, and our findings are consistent with those other studies found in Turkey. In our study, while the rates of CVC and urinary cathete rutilization were similar,the rates of CVCR-BSI and CR-URI were lower. Inlight of these data, it can be asserted that the inspections are carried out properly in ICUs in our hospital, and the precautions to be taken, especially in inserting catheters, are performed meticulously.

In different studies, pneumonia has been identified as one of the most widespread NIs $(15,16)$. The National Nosocomial Infections System (NNIS) in the USA defines nosocomial pneumonia as one of the most common infections encountered in ICUs. The widespread utilization of mechanical ventilation and tracheal intubation, especially in critically ill patients, causes the risk of hospital pneumonia to increase (9). In our study, pulmonary infections were determined as the most common Nls with the rate of $80.9 \%$ (LRTIOP 36.8\%, pneumonia with specific laboratory findings $33.6 \%$ and VAP $10.5 \%$, respectively). Pulmonary infections were followed by BSIs (15.7\%) (CVCR-BSI 9.4\% and laboratory-proven BSI 6.3\%, respectively) and CR-URI (3.1\%). Gram-negative bacteria are among the leading causes of NIs (17-19). When the factors of all Nls were evaluated in our study, Gram-negative pathogens (93.1\%) were seen to rank first. In the study conducted by Akin et al., Gram-negative bacteria were isolated as the mos tcommon infection agents in ICU. As consistent with our study findings, A. baumannii was the most frequently detected agent in the study by Akin et al. However, among Grampositive bacteria, $S$. aureus was the most frequently isolated strain (20). In our study, CNS was detected to rank first. In a study examining Nls over a four-yea rperiod, Acinetobacter spp. (42.4\%), K. pneumoniae (22.2\%) and P. aeruginosa (14.8\%) were found as the most widespread agents in pneumonia (21). In another study conducted in China, A. baumannii was found to be the mos tcommon pathogen among the lower respiratory tract infections in ICU with the rate of $18.9 \%$ (22). In our study, however, Acinetobacter spp. Ranked first among the lower respiratory tract infections. When pulmonar yinfections were looked at in detail, Acinetobacter spp. (48.7\%), K. pneumoniae (25.6\%) and P. aeruginosa (12.8\%) were detected as the most widespread pathogens among other lower respiratory tract infections, Acinetobacter spp. (72.7\%), K. pneumoniae (12.1\%) and E. coli (6\%) were determined as the causative agents in pneumonia with specific laboratory findings, as well as Acinetobacter spp. (75\%), K. pneumoniae (16.6\%) and $P$. aeruginosa (8.8\%) as the most widespread agents in VAP. According to the NNISN 2019 report over the distribution of agents and antibiotic resistance, Klebsiella spp. (19.9\%) was foundto be the most common agent across Turkey. Our findings are consistent with those reported in other studies from Turkey. In the same report, Klebsiella spp. (30\%) and E. coli (24\%) were stated as the agents ranking first and second. In another study, however, K. pneumoniae (54.5\%) was found to rank first in CR-Url, followed by E. coli (18.1\%) and E. faecalis (18.1\%) (23). As similar tothe data in the NNISN 2019 report, K. pneumoniae (33.3\%), M. morganii (33.3\%) and E. faecalis (33.3\%) were determined as the causative agents in CR-URI in our study. NIs cause an increase in mortality and morbidity, and so the hospitalization periods of the patients are prolonged. Inourstudy, the mortality rate wasfound as $51.1 \%$ in the patients hospitalized in ICU and presentingwithNIs. In several studies performed in Turkey and other countries, the mortality rates have shown to increase among the inpatients presenting with NIs $(10,22-28)$. The higher rates of NIs among the patients treated and followed-upin ICUs, It can be considered to stem from other factors such as the presence of underlying diseases, the advanced age of the patients in ICUs and the severity of the disease as a reason for hospitalization and contributing to the morbidity and mortality. 


\section{ETHICAL DECLARATIONS}

Ethics Committee Approval: The study was approved by the University of Medical Sciences Konya Training and Research Hospital of Specialty in Medical Training (TUEK), dated on 5th March 2020 and with the registration number of 36-31.

Informed Consent: All patients signed the free and informed consent form.

Referee Evaluation Process: Externally peer-reviewed.

Conflict of Interest Statement: The authors have no conflicts of interest to declare.

Financial Disclosure: The authors declared that this study has received no financial support.

Author Contributions: All of the authors declare that they have all participated in the design, execution, and analysis of the paper, and that they have approved the final version.

\section{CONCLUSION}

Based on our study findings, it is inevitable to see NIs in hospitals, especially in ICUs, and one of the crucial health goals of the hospitals is to control and manage such a situation. Timely and appropriate therapeutic interventions should be carried out in order to reduce the rates of Nls. If needed, catheters should be inserted with the accurate indication, and/ or the procedures performed via catheters should be reduced. Considering the importance of ICUs in the development of $\mathrm{NIs}$, healthcare staff in ICUs should be given a full healthcare training. Additionally, due to highe rincidence of Nls, hospitals are also recommended to develop rational antibiotherapy programs, based on thei rown surveillance data.

\section{REFERENCES}

1. Edwardson S, Cairns C. Nosocomial infections in the ICU. Anaesthesia\&Intensive Care Medicine. 2019: 20(1) ; 14-18.

2. Karabey S. Hastane Enfeksiyonları: Tanımlar Doğanay M, Ünal S, editörler. Hastane İnfeksiyonları. Ankara: Bilimsel Tıp Yayınevi; 2013: 35-57.

3. Yılmaz N, Köse Ş, Ağuş N, Ece G, Akkoçlu G, Kıraklı C. Yoğun bakım ünitesinde yatan hastaların kan kültürlerinde üreyen mikroorganizmalar, antibiyotik duyarlılıkları ve nozokomiyal bakteriyemi etkenleri. Ankem Derg 2010; 24: 12-9.

4. İnan D, Saba R, Keskin S, Öğünç D, Çiftçi C, Günseren F, et al. Akdeniz Üniversitesi Hastanesi yoğun bakım ünitelerinde hastane infeksiyonları. Yoğun Bakım Dergisi 2002; 2: 129-35.

5. Erol, S. Hastane enfeksiyonları sürveyansı. Hastane Enfeksiyonları Korunma ve Kontrol Sempozyumu (Sempozyum Kitabı) İstanbul. 2008: 43-51.

6. Clinicaland Laboratory Standard Institute (CLSI). Performance Standards for Antimicrobial Susceptibility Testing; 20th Informational Supplement (June 2010, Update). CLSI document M100-S20-U. CLSI, Wayne, PA: Clinical and Laboratory Standard Institute, 2010.

7. Horan TC, Andrus M, Dudeck MA. CDC/NHSN surveillance definition of healthcare-associated infection and criteria for specific types of infections in the acute care setting. Am J Infect Control. 2008; 36(5): 309-32.

8. Şahin AR, Tuğan Yıldız B, Aktemur A, Topal B, Nazik S, Ateş S. Evaluation of nosocomial infections in a neurological intensive care unit of a university hospital. J Contemp Med. 2019; 9(1): 43-7.

9. Gholsha R, Ashuri N, Tajik M, Sohrabi A, Montazeri M. Prevalence of Nosocomial Infections in Intensive Care Units in Shahid Sayyad-E-Shirazi Hospital of Gorgan During 2016-2018. Tabari Biomed StuRes J. 2020; 2(2): 48-57.
10. Ghashghaee A, Behzadifar M, Azari S, Farhadi Z, LuigiBragazzi N, Saeedi SS et al. Prevalence of nosocomial infections in Iran: A systematic reviewand meta-analysis. Med J IslamRepub Iran. 2018; 32:48.

11. Özer Balin \$̧, Denk A. Harput Devlet Hastanesi Yoğun Bakım Ünitesinde 2013-2014 Yılı İnvaziv Alet İlişsili Hastane Enfeksiyonlarının Değerlendirilmesi. FiratMed J. 2016; 21(1): 24-28.

12. Öncül A, Koçulu S, Elevli K. Bir devlet hastanesinin yoğun bakım ünitelerinde kazanılan hastane enfeksiyonlarının epidemiyolojisi. Şişli Etfal Hastanesi Tıp Bülteni 2012; 46(2): 60-6.

13. Eroğlu E. Nöroloji Yoğun Bakım Ünitesinde Gelişen Hastane Enfeksiyonlarının Değerlendirilmesi. Turkiye Klinikleri J InternMed. 2020;5(2):49-54.

14. Ulusal Hastane Enfeksiyonları Sürveyans Ağı (UHESA) raporu özet veri. 2019. https://hsgm.saglik.gov.tr/depo/birimler/Bulasici-hastaliklar-db/ hastaliklar/SHIE/Raporlar/USHESA_Ozet_Raporu_2019.pdf

15. Chastre J, Fagon J-Y. Ventilator-associated pneumonia. American journal of respiratory and critical care medicine. 2002;165(7):867- 903.

16. Society AT. Infectious Diseases Society of America. Guidelines for the management of adults with hospital-acquired, ventilator associated, and healthcare-associated pneumonia. Am J Respir Crit Care Med. 2005;171:388-416.

17. Malik A, Hasani S, Shahid M, Khan H, Ahmad A. Nosocomial Klebsiella infection in neonates in a tertiary care hospital: protein profile by SDSpageandklebocintyping as epidemiological markers. Indian Journal of MedicalMicrobiology. 2003; 21(2): 82.

18. Roberts JA, Paul SK, Akova M, Bassetti M, De Waele JJ, Dimopoulos G et al. DALI: defining antibiotic levels in intensive care unit patients: are current $\beta$-lactam antibiotic doses sufficient for critically ill patients? Clinical infectious diseases. 2014; 58(8): 1072-83.

19. Kollef $\mathrm{MH}$, Fraser VJ. Antibiotic resistance in the intensive care unit. Annals of internal medicine. 2001; 134(4): 298-314.

20. Akın A, Esmaoğlu Çoruh A, Alp E, Günay Canpolat D. Anestezi Yoğun Bakım Ünitesinde Beş Yıl içerisinde Gelişen Nozokomiyal Enfeksiyonlar ve Antibiyotik Direncinin Değerlendirilmesi. Erciyes Medical Journal. 2011; 33(1): 7-16

21. Karahocagil MK, Yaman G, Göktaş U, Sünnetçioğlu M, Çıkman A, Bilici A. Hastane Enfeksiyon Etkenlerinin ve Direnç Profillerinin Belirlenmesi Van Tıp Dergisi: $2011 ; 18$ (1): 27-32.

22. Ding J-G, Sun Q-F, Li K-C, Zheng M-H, Miao X-H, Ni W. Retrospective analysisof Nosocomial infections in the intensive care unit of a tertiary hospital in China during 2003 and 2007. BMC Infection Diseases. 2009;9:115.

23. Ulusal Sağlık Hizmeti İlişkili Enfeksiyonlar Sürveyans Ağı (USHiESA) Etken Dağılımı ve Antibiyotik Direnç Raporu. 2019. https://hsgm.saglik.gov.tr/ depo/birimler/Bulasici-hastaliklar-db/hastaliklar/SHIE/Raporlar/ETKEN_ DAGILIM_VE_DIRENC_2019.pdf

24. Vincent JL, Bihari DJ, Suter PM, Bruining HA, White J, Nicolas-Chanoin MH et al. The prevalence of nosocomial infection in intensive care units in Europe: results of the European Prevalence of Infection in Intensive Care (EPIC) Study. Jama 1995; 274(8), 639-44.

25. Çakır E, Kocabeyoğlu GM, Gürbüz Ö, Baltacı Özen S, Mutlu NM, Özkoçak Turan İ. Yoğun Bakım Ünitesinde Mortalite Sıklığı ve Risk Faktörlerinin Değerlendirilmesi. Ankara Eğitim ve Araştırma Hastanesi Tıp Dergisi. 2020; 53(1):20-4.

26. Vincent JL, Rello J, Marshall J, Silva E, Anzueto A, Martin CD et al. International study of the prevalence and outcomes of infection in intensive care units. Jama 2009; 302(21), 2323-29.

27. Çevik MA, Yılmaz GR, Erdinç FŞ, Üçler S, Tülek N. Nöroloji yoğun bakım ünitesinde mortalite ile ilişkili faktörler ve nozokomiyal infeksiyonla mortalitenin ilişkisi. Yoğun Bakım Dergisi 2001;1:47-55.

28. Tarakçı A, Erayman İ, Kandemir B, Eroğlu E. Bir Üniversite Hastanesi Yoğun Bakım Ünitelerinde Gelişen Hastane Enfeksiyonlarının Değerlendirilmesi. Ahi Evran Uluslararası Tıp ve Sağlık Bilimler Kongresi. 2019; 305, 551-55. 